Original Research

\title{
Tuberculosis Knowledge among University Students in Indonesia
}

\author{
Miftahul Falah', Chun-Yi Tai' ${ }^{2}$, Yu-Ying Lu², Chieh-Yu Liu², Lilis lismayanti
}

${ }^{1}$ University of Muhammadiyah Tasikmalaya

${ }^{2}$ The National Taipei University of Nursing and Health Sciences

\section{Article Info}

Article History:
Accepted September 30th,
2019

Key words:

Tuberculosis; Knowledge; Indonesia

\section{INTRODUCTION}

The rising tuberculosis (TB) incidence has become one of the main health issues in the world. Although some interventions for the prevention and treatment of TB have been developed, the incidence and mortality rates of TB continue increasing (Easwaran et al., 2015; Depkes, 2011). According to the World Health Organization (WHO) (2017), there were 360,565 patients with TB in Indonesia. The Indonesian Ministry of Health also reported that TB was the fourth leading cause of death in Indonesia, and 6, 371 patients developed TB in 2014. In addition, most of these new cases were adults aged between 25-34 (17.18\%), 35$44 \quad(17.18 \%)$, and 45-54 (17.33\%) (Kemenkes, 2015). Furthermore, TB could cause significant mortality and morbidity in a community (Murray et al., 2014).

The high prevalence of tuberculosis impacts society, economy and the environment. One study from Nigeria found that TB patients' friends frequently

Corresponding author:

Miftahul Falah

miftahulfalah57@gmail.com

South East Asia Nursing Research, Vol 1 No 2, September 2019

ISSN:2685-032X

DOI: https://doi.org/10.26714/seanr.1.2.2019.95-105 
have a discriminatory attitude towards them (Asuquo et al., 2014) due to the stigma linked to the disease (Dhuria, Sharma, \& Ingle, 2008). The disease has social implications: most patients in one study conducted in Mexico reported losing their sense of identity, including loss of productivity and relationships with family, resulting in a severe perception of isolation (Morris et al., 2013). Moreover, a study found that the costs associated with the illness impoverish many households, because many patients accumulate debt and experience loss of income and productive farm assets. Among the 160 cases of TB in this study conducted in China, most of the TB patients were household heads, the primary source of income for their households. After being diagnosed, they lost opportunities to work due to social stigma and the effects of the disease. As a result, $30 \%$ of the cases in that study earned incomes below the official poverty line (Jackson, Sleigh, Wang, \& Liu, 2006). In Mexico, patients' inability to work and their uncertainty about how TB would affect their ability to survive financially appeared to reduce their sense of worth (Morris et al., 2013).

The reason TB patients gave most frequently to explain their non-adherence to treatment in Indonesia was lack of money to pay for fees and transportation (Widjanarko, Gompelan, Dijkers, \& der Werf, 2009). A study aiming to estimate a patient's cost for tuberculosis diagnosis and treatment from the patient's perspective found that these costs are a significant economic burden on patients in Zambia. Moreover, the three largest predictors of patient costs are treatment supervision strategy, patients' delays in seeking care and gender (Amsler et al., 2008). Furthermore, TB has a significant impact on quality of life of patients in several domains, including patient's environment and their psychological wellbeing (Dhuria et al., 2009). Many studies have shown that the environment has a great impact on TB transmission. For example, a study from Brazil demonstrated that the transmission of TB is directly linked to the community's living conditions (Farias et al., 2013). Therefore, the condition of patients' homes needs to be investigated, prioritizing those cases with inappropriate ventilation and overcrowding, as closed environments facilitate transmission and domestic contacts put potential patients at greatest risk of catching the disease (Kemenkes, 2014). Conversely, other studies have reported that TB negatively affects quality of life in the environmental domain, such as sense of safety, transportation, financial security, quality and accessibility of health and social care, and opportunities for leisure activities. Other studies also found that TB's impact was the greatest on quality of life in the environmental and psychological domains (Dhuria et al., 2009; Sule et al., 2014).

Students' lack of knowledge about TB is one factor that causes the high incidence of TB in Indonesia. Specifically, lack of knowledge about the cause, prevention, transmission, and symptoms of TB result in poor behavior seeking treatment. For example, the National TB Team program of Indonesia reported that many TB patients stop taking medication before they fully recover, as they do not know that the disease can become latent and that improvement in symptoms does not necessarily indicate a cure (Depkes, 2011). Seeking proper treatment mainly depends on peoples' knowledge about TB and their perception of risks associated with it (Uchenna et al., 2014). For instance, patients in many countries believe that TB is hereditary and incurable. Due to such false perceptions regarding $\mathrm{TB}$, patients may have less motivations to manage their symptoms (Dewi, Barclay, Passey, \& Wilson, 2016; Hoa, Chuc, \& Thorson, 2009). One study of 748 participants with suspected TB in Indonesia found that $11.3 \%$ had not yet sought care and approximately $33 \%$ would rather seek care from traditional health practitioners than 
health professionals (Ahmad, Richardus, \& de Vlas, 2012). Moreover, adherence to isoniazid preventive therapy (IPT) for TB in Indonesia is low (Rutherford et al., 2012). Conversely, patients who have accurate knowledge of TB may seek more care. The more frequent they seek care, the more knowledge they have about TB. This is because patients can be given correct information while getting treatment from health care providers (Yousif, Donaldson, \& Husseynova, 2011). Hossain et al. (2015) reported that accurate knowledge is an important factor in predicting patients' care seeking behaviors. Therefore, it is essential for governments to develop intervention programs that promote knowledge, prevention, and treatment of TB.

The Indonesian government recommends conducting more research on TB prevention in Indonesia (Depkes, 2011). A number of studies have been done in Indonesia about prevention of and rehabilitation from TB. Some have screened people for TB (Lock et al., 2011; Triasih et al., 2016). Few studies have focused on patients' knowledge about TB. These revealed that knowledge among people suspected of having TB living in Yogyakarta had a moderate level of knowledge about the disease, whereas others had low knowledge (Ahmad, Richardus, \& de Vlas, 2012; Lock et al., 2011). Patients with inadequate knowledge of TB were at higher risk of getting inadequate treatment compared to patients who had acquired more information about TB (Fatiregun, Ojo, \& Bamgboye, 2009). Therefore, this study is investigating knowledge about TB among students in Indonesia. This will be one of the first studies to evaluate knowledge about TB in a non-patient population.

\section{METHODS}

This study used a cross-sectional descriptive study design. This study was conducted at the University of
Muhammadiyah Tasikmalaya in Indonesia. Total population of this study were all students who study at the University of Muhammadiyah Tasikmalaya in Indonesia, numbering 1.500 students in total. The sample of this study was students with health-related and non-health-related major at the University of Muhammadiyah Tasikmalaya in Indonesia. The sample size was 200 students. A convenience sample method used in this study. In this study, the researcher used a TB knowledge questionnaire developed by Dr. Lock and his colleagues in 2011. Then this instrument asked participants to provide demographic information, including age, gender, educational background, residential area, ethnicity, marital status, major field of study, TB experience, TB xray, TB screening, wearing a mask, and family history of TB. Prior to implementing the study, the researcher trained a research assistant to collect data. After obtaining permission from the Institutional Review Board (IRB), the research assistant collected the questionnaire. After collecting the questionnaires, the researcher went through the questionnaire to ensure completeness and examined the number of eligible students. Each participated student was then assigned a study ID for data entry, and then the researcher calculated a total score based on the participants' responses, then enter the data to SPSS. Univariate analyses utilized, such as t-test and oneway ANOVA were used to test the knowledge score between different levels of categorical variables. Pearson correlations coefficients were used for investigating correlation between continuous variables. Furthermore, multiple linear regressions were used to understand which factors can predict TB knowledge.

\section{RESULTS}

This chapter describes the characteristics of the study population, which aims to present the principle findings of the study related to differences in knowledge among 
university students in Muhammadiyah University of Tasikmalaya, Indonesia. Different statistical methods were used to ascertain the features of the studied population and to display tendencies in the data gathered.

\section{Descriptive Statistics of the Study Population}

A total of two hundred students were recruited and interviewed for this study. All participated students were studying in Muhammadiyah University of Tasikmalaya, Indonesia at the time of recruitment.

The mean age of the students was 21.46 $(\mathrm{SD} \pm 1.982)$ at the time of data collection ranging from 18 to 27 years old. The majority of the respondents were male, with 124 (62\%) males and 76 (38\%) females. Among several ethnicities, students of Sunda ethnicity outnumbered the others. Of the students included in the study population, 163 (81.5\%) were Sundan ethnicity, 30 (15\%) were Javans, 3 $(1.5 \%)$ were Betawis and 4 (2\%) were Malays.

Regarding educational background, the majority of the students ( $n=161,80.5 \%)$, had completed senior high school (SMA). A total of $36(19.5 \%)$ students had specific high school (SMK) education. Most of the students were single or widowed $(n=162$, $81 \%)$, and about 38 (19\%) were married.

More than half of the students $(n=106$, $53 \%)$ lived in rural areas, and 94 (47\%) lived in urban areas. According to their major field of study, the majority of the students $(n=130,65 \%)$ were pursuing health related studies, with $47(23.5 \%)$ in education and $23(11.5 \%)$ in engineering.

Most of the students ( $n=191,95.5 \%$ ), had heard about TB, and only 9 (4.5\%) had not heard about the disease. More than half of the students $(n=165,82.5 \%)$ had not had an X-ray for TB, and only 35 (17.5\%) students had one. The same number of students had been screened for TB.

According to the students, about 120 (60\%) students had worn masks, and 80 $(40 \%)$ had not. The majority of the students ( $n=166,83 \%)$, did not have a family member with TB, and only 34 (17\%) did have family with TB.

Table 1

Demographic Characteristics of the Students

\begin{tabular}{|c|c|c|c|c|}
\hline Indicators & $\mathrm{n}$ & $\%$ & Mean $\pm S D$ & Range \\
\hline Age & & & $21.46 \pm 1.982$ & $18-27$ \\
\hline \multicolumn{5}{|l|}{ Gender } \\
\hline Male & 124 & 62.0 & & \\
\hline Female & 76 & 38.0 & & \\
\hline \multicolumn{5}{|l|}{ Ethnicity } \\
\hline Sunda & 163 & 81.5 & & \\
\hline Java & 30 & 15.0 & & \\
\hline Betawi & 3 & 1.5 & & \\
\hline Malay & 4 & 2.0 & & \\
\hline \multicolumn{5}{|c|}{ Educational background } \\
\hline $\begin{array}{l}\text { Senior high } \\
\text { school (SMA) }\end{array}$ & 161 & 80.5 & & \\
\hline $\begin{array}{l}\text { Specific high } \\
\text { school (SMK) }\end{array}$ & 39 & 19.5 & & \\
\hline \multicolumn{5}{|l|}{ Marital status } \\
\hline $\begin{array}{ll}\text { Single } & \text { or } \\
\text { widowed } & \end{array}$ & 162 & 81.0 & & \\
\hline Married & 38 & 19.0 & & \\
\hline \multicolumn{5}{|l|}{ Residential area } \\
\hline Urban & 94 & 47.0 & & \\
\hline Rural & 106 & 53.0 & & \\
\hline \multicolumn{5}{|l|}{ Major field study } \\
\hline $\begin{array}{l}\text { Health-related } \\
\text { studies }\end{array}$ & 130 & 65.0 & & \\
\hline Education & 47 & 23.5 & & \\
\hline Engineering & 23 & 11.5 & & \\
\hline \multicolumn{5}{|l|}{ Heard of TB } \\
\hline No & 9 & 4.5 & & \\
\hline Yes & 191 & 95.5 & & \\
\hline \multicolumn{5}{|l|}{ Had X-ray for TB } \\
\hline No & 165 & 82.5 & & \\
\hline Yes & 35 & 17.5 & & \\
\hline \multicolumn{5}{|l|}{ Had TB screening } \\
\hline No & 165 & 82.5 & & \\
\hline Yes & 35 & 17.5 & & \\
\hline \multicolumn{5}{|l|}{ Wear masks } \\
\hline No & 80 & 40.0 & & \\
\hline Yes & 120 & 60.0 & & \\
\hline \multicolumn{5}{|l|}{$\begin{array}{l}\text { Family member } \\
\text { with TB }\end{array}$} \\
\hline No & 166 & 83.0 & & \\
\hline Yes & 34 & 17.0 & & \\
\hline
\end{tabular}




\section{Statistically Significant Differences between Demographic Characteristics and Students' Knowledge}

This study used Pearson correlation, t-test, and one-way ANOVA to determine the relationships among demographic factors and students' knowledge (table 2). An independent- sample t-test showed that gender [male $(M=9.81, S D=2.38)$, female $(M=8.95, \quad S D=2.61)]$ was significantly associated with knowledge [ $\mathrm{t}(198)=2.40$, $\mathrm{p}=.017]$. These results suggest that gender has an effect on knowledge. Similarly, there was a significantly related between educational background [SMA $(\mathrm{M}=9.28$, $\mathrm{SD}=2.53)$, $\mathrm{SMK}(\mathrm{M}=10.33, \mathrm{SD}=2.20)]$ and knowledge [t (198) $=-2.39, \mathrm{p}=.018$ ]. Likewise, major field of study and knowledge showed a significant relationship $[\mathrm{F}(2,197)=21.82, \mathrm{p}=.000]$. In addition, students who have heard of TB [yes $(\mathrm{M}=9.57, \mathrm{SD}=2.40)$, no $(\mathrm{M}=7.67, \mathrm{SD}=$ 3.70)] was significantly associated with having knowledge about TB [ $\mathrm{t}$ (198) = $2.25, \mathrm{p}=.025]$.

On the other hand, most variables included in this study showed no statistically significant association with TB knowledge. For example, Pearson correlation test found there was no correlation between age and TB knowledge $(\mathrm{r}=.138, \mathrm{n}=200, \mathrm{p}=$ .052). Similarly, ethnicity had no statistically significant association with TB knowledge [t (198) $=1.09, \mathrm{p}=$.277]. Moreover, no statistically significant relationship was found between marital status [single or widowed $(\mathrm{M}=9.49, \mathrm{SD}=$ $2.40)$, married $(\mathrm{M}=9.45, \mathrm{SD}=2.89)]$ and $\mathrm{TB}$ knowledge [t (198) = .103, $\mathrm{p}=.918]$. Similarly, the results showed there was no significant association between residential area [urban $(\mathrm{M}=9.38, \mathrm{SD}=2.76)$, rural $(\mathrm{M}=9.58, \mathrm{SD}=2.26)$ and knowledge [t (198) $=-.542, \mathrm{p}=.588]$. Surprisingly, a family member having TB [yes $(\mathrm{M}=10.1, \mathrm{SD}=$ 2.49), no $(\mathrm{M}=9.35, \mathrm{SD}=2.49)]$ did not correlate with TB knowledge [t (198) = $1.703, \mathrm{p}=.090]$.
Furthermore, having had an X-ray for TB [yes $(\mathrm{M}=10.1, \mathrm{SD}=2.46)$, no $(\mathrm{M}=9.35, \mathrm{SD}=$ 2. 50)] was not statistically significant related with knowledge about $\mathrm{TB}$ [t (198) = $-1.65, p=.101]$. The same result found in having TB screening. Moreover, there was no statistically significant association found between having wear masks [yes $(M=9.62$, $\mathrm{SD}=2.40)$, no $(\mathrm{M}=9.29, \mathrm{SD}=2.64)$ and $\mathrm{TB}$ knowledge [t (198) $=-.912, \mathrm{p}=.363$ ].

\section{Predicting Knowledge of Students at Muhammadiyah University of Tasikmalaya (UMTAS).}

A stepwise multiple regression analysis was conducted to determine the best linear combination of sub-dimensions of sociodemographic factors related to $\mathrm{TB}$ knowledge among university students in Indonesia. The result found major field of study and educational background were recognized as predictive factors. Specifically, as shown in Table 3 that major field of study (standardized coefficients $\beta=$ - .409, $p=.000$ ) and educational background (standardized coefficients $\beta=$ $.181, p=.005$ ) significantly predicted knowledge about TB among Muhammadiyah University students in Indonesia.

The unstandardized coefficient for major field of study was ( $\beta=-1.475)$, which indicated that students who were not pursuing health-related studies were more likely to have lower knowledge scores. For educational background, the unstandardized coefficient score was positive $(\beta=1.141)$, which indicates that students who had a Specific High School (SMK) education had greater knowledge than Senior High School (SMA). 
Table 2

Mean Knowledge Scores of Students with Demographic Characteristics

\begin{tabular}{|c|c|c|c|c|c|}
\hline Variables & $\mathrm{n}$ & Mean \pm SD & $\mathrm{t} / \mathrm{F} / \mathrm{r}$ & $\mathrm{p}$ & LSD \\
\hline Age & & $21.46 \pm 1.982$ & $.138^{\mathrm{c}}$ & .052 & \\
\hline Gender & & & $2.40^{\mathrm{b}}$ & $.017^{* *}$ & \\
\hline Male & 124 & $9.81 \pm 2.380$ & & & \\
\hline Female & 76 & $8.95 \pm 2.612$ & & & \\
\hline Ethnicity & & & $1.09 \mathrm{~b}$ & .277 & \\
\hline Sunda & 163 & $9.58 \pm 2.454$ & & & \\
\hline Non-sunda & 37 & $9.08 \pm 2.691$ & & & \\
\hline Educational background & & & $-2.39^{b}$ & $.018^{* *}$ & \\
\hline Senior high school (SMA) & 161 & $9.28 \pm 2.530$ & & & \\
\hline Specific high school (SMK) & 39 & $10.33 \pm 2.204$ & & & \\
\hline Marital status & & & $.103^{\mathrm{b}}$ & .918 & \\
\hline Single or widowed & 162 & $9.49 \pm 2.409$ & & & \\
\hline Married & 38 & $9.45 \pm 2.892$ & & & \\
\hline Residential area & & & $-.542^{b}$ & .588 & \\
\hline Urban & 94 & $9.38 \pm 2.756$ & & & \\
\hline Rural & 106 & $9.58 \pm 2.259$ & & & \\
\hline Major field of study & & & $21.82^{\mathrm{a}}$ & $<.001^{* * *}$ & \\
\hline Health-related studies & 130 & $10.26 \pm 1.895$ & & & $1>2$ \\
\hline Education & 47 & $8.15 \pm 2.750$ & & & $1>3$ \\
\hline Engineering & 23 & $7.83 \pm 3.070$ & & & $2>3$ \\
\hline Heard of TB & & & $-2.25^{b}$ & $.025^{* *}$ & \\
\hline No & 9 & $7.67 \pm 3.708$ & & & \\
\hline Yes & 191 & $9.57 \pm 2.409$ & & & \\
\hline \multicolumn{6}{|l|}{ Had X-ray for TB and Had TB screening } \\
\hline No & 165 & $9.35 \pm 2.496$ & $-1.65^{b}$ & .101 & \\
\hline Yes & 35 & $10.11 \pm 2.459$ & & & \\
\hline Wear masks & & & $-.912^{b}$ & .363 & \\
\hline No & 80 & $9.29 \pm 2.649$ & & & \\
\hline Yes & 120 & $9.62 \pm 2.398$ & & & \\
\hline \multicolumn{6}{|l|}{ Family Member with TB } \\
\hline No & 166 & $9.35 \pm 2.488$ & $-1.70^{b}$ & .090 & \\
\hline Yes & 34 & $10.15 \pm 2.488$ & & & \\
\hline
\end{tabular}

Note. ${ }^{* *} p<.05 .{ }^{* * *} p<.01 ; \mathrm{TB}$, tuberculosis; a F-values from one-way ANOVA; b Independent t-test; c Pearson correlation; LSD $=$ Post Hoc.

Table 3

Predictors of TB knowledge

\begin{tabular}{|c|c|c|c|c|c|}
\hline \multirow[t]{2}{*}{ Variables } & \multicolumn{2}{|c|}{ Unstandardized coefficients } & \multirow{2}{*}{$\begin{array}{c}\begin{array}{c}\text { Standardized } \\
\text { coefficients }\end{array} \\
\text { Beta }\end{array}$} & \multirow[t]{2}{*}{$\mathrm{t}$} & \multirow[t]{2}{*}{$\mathrm{p}$} \\
\hline & $B$ & $S E B$ & & & \\
\hline Constant & 10.282 & .600 & & 17.142 & $<.001^{* * *}$ \\
\hline Major field of study & -1.475 & .230 & -.409 & -6.399 & $<.001^{* * *}$ \\
\hline Educational background & 1.141 & .403 & .181 & 2.836 & $.005^{* *}$ \\
\hline
\end{tabular}

\footnotetext{
Note:

a. Dependent Variable: Knowledge

b. Predictors in the Model: Major field of study, Educational background

*** $\mathrm{p}<.01$ *** $^{*}<.05 ; \mathrm{B}$, beta; SEB, std. error.

$\mathrm{R}=.509, \mathrm{R}^{2}=.25$, Adjusted $\mathrm{R}^{2}=.215$
} 


\section{DISCUSSION}

This study explored knowledge of tuberculosis among university students in Indonesia. The respondents were students at the Muhammadiyah Tasikmalaya University, Indonesia. The mean age of the students was 21.46 years at the time of data collection. Their ages ranged from 18 to 27 years. A majority of the students, 124 (62\%), were male. The mean TB knowledge score among the students was 9.49 (SD \pm 2.500 ) out of 14 possible points. Knowledge scores ranged from 2 to 14 items correctly answered.

\section{Demographic factors associated with TB knowledge}

This study findings showed that there are several factors, such as gender, educational background, major field of study and having heard about $\mathrm{TB}$, related to knowledge about TB. In addition, major field of study and educational background were predictors of TB knowledge levels among students in Muhammadiyah University of Tasikmalaya.

\section{Gender associated with knowledge}

With few exceptions, studies worldwide find gender is a significant factor in knowledge about disease, although the patterns differ. Results from Vancouver, Canada showing no significant relationship between gender and knowledge about hepatitis B, are exceptional (Leung et al., 2006).

The study found that gender had a statistically significant relation with knowledge of TB among university students in Indonesia. According to the results, men had greater knowledge about TB than women. The difference in knowledge between male and female students might be attributed to differences in access to information, media and participation in different social groups.
These results are supported by those of other studies in some developing countries. A study by Wang and colleagues (Wang, Fei, Shen, \& Xu, 2008) about knowledge of TB in the rural Chinese population found differences TB knowledge among males and females. Females had lower knowledge about TB health services and were comparatively unwilling to receive information about TB than males. Moreover, Females did not seem to get information about TB and share it with other people. However, females were more likely to seek health care and go to village clinics, yet males preferred to seek health care at high-level hospitals.

This pattern of greater knowledge about disease among men does not break down neatly according to a society's level of economic development. One can see this pattern in developing countries, for example, a study in Vietnam showed that, of a total sample of 559, most of women $82 \%$ did not know that TB is caused by bacteria (Hoa, Thorson, Long, \& Diwan, 2003). Likewise, males had significantly higher knowledge scores about TB disease than females in Sudan (Mohamed, Yousif, Ottoa, and Bayoumi, 2007).

In contrast, some studies in developing countries have found women to have more health knowledge than men. For example, in a study about HIV/AIDS knowledge in Ghana, results consistently showed significant gender differences among undergraduate university students, with women having greater knowledge than men (Asante \& Boadi, 2013). In Colombia, a study found that women more frequently had correct responses to questions about dengue fever and its transmission. This could suggest that women in Columbia may be more interested in or sensitive to acquiring skills that allow them to recognize the disease and prevent its transmission (Diaz-Quijano et al., 2018). In Malaysia, a study about factors associated with knowledge related to hepatitis B and C found that a significantly higher proportion 
of female respondents had better knowledge of hepatitis C, compared with males (Ahmad, Sann, \& Rahman, 2016).

In Bangladesh, men had greater awareness than women about TB disease, TB latency and Directly Observed Treatment, while on the other hand, Bangladeshi women had more knowledge about the bacterial cause of the disease and its curability than men. This gender difference may reflect the culture and lifestyles in Bangladesh. Much of the time, mothers and daughters stay at home and are more prone to enjoy TV, which, however is a relatively poor source of information. They are comparatively less exposed to markets or public places. On the other hand, men are more exposed to markets, hospitals and other public places. So, they have more chances to gain information from varied sources, such as billboards, posters and friends, in addition to TV (Rana et al., 2015).

Worldwide, differences in knowledge about transmissible disease between men and women are common. However, follow few obvious patterns. In both developed and developing countries, one sex or the other was better informed. The reasons for these differences in knowledge levels among men and women remain mostly unproven and speculative. Yet are understood to be social in origin.

\section{Education associated with knowledge}

This study found that educational background was significantly associated with knowledge about TB among university students in Indonesia. Results from the students show that students who had a Specific High Schools (SMK) education had greater knowledge than those who went to Senior High School (SMA). This result might be influenced by the courses that they got from the school. For example, Specific High School (SMK) had more courses related to the health knowledge and they do also practice how to prevent some disease.
This finding supported by others studies. For example, a study about TB knowledge and factors affecting case detection under the national TB control program (NTP) in Bangladesh found that low education was related with poor knowledge about TB. It shows that information of TB is not reaching less educated people in an effective method (Hossain et al., 2015). Moreover, a study by Yin et al. (2013) showed that elderly participants who had finished high school education or above had better odds of possessing adequate health knowledge than those whose highest education level was below junior high school. This finding is similar with other studies, for example, a study by Freitas et al. (2015) and Hoa, Chuc, \& Thorson (2009), reported that higher education levels were related with greater awareness and willingness to seek information about TB.

Moreover, the Sudanese study on knowledge of tuberculosis and its treatment among TB patients found a general low of awareness of the disease and its treatment, but higher educational levels will increase the level of satisfactory knowledge (Mohamed, Yousif, Ottoa, and Bayoumi, 2007). Similarly, a study of knowledge and misconceptions about TB in the general population in Serbia found that education level was a predictor of right understanding about modes of transmission (Vukovic, Obradovic, \& Bjegovic, 2008). a study in Nigeria found that the educational status of participants and their spouses was linked with TBrelated knowledge, attitudes and practices (Uchenna et al., 2014). Moreover, people who had post-secondary education were more likely to be knowledgeable about the importance of completing tuberculosis treatment in Kenya (Ndwiga, Kikuvi, \& Omolo, 2016). In Tanzania, schooling likewise proved to have a significant positive effect on TB knowledge (Haasnoot, Boeting, Kuney, \& Roosmalen, 2010). Also, another study in the USA, patients who had completed six or more years of schooling 
were significantly to have sufficient knowledge about TB (Mondal, Nazrul, Chowdhury, \& Howard, 2014).

The relationship between education and adequate knowledge about TB is straightforward: none of these studies reported that people with more formal schooling knew less than others about TB, its causes, transmission and treatment.

\section{Associations between major field of study and TB knowledge}

Major field of study had a significant association with knowledge about TB among university students in Indonesia. Results from the students show that students who were not pursuing healthrelated studies were less likely to have high knowledge scores. This may be attributed to the fact that education and engineering majors do not have lectures in heath topics that could convey knowledge about TB. But students pursuing health-related majors necessarily have lectures that include knowledge related to TB.

This association between major field and health knowledge has been proven in several studies. For example, a study in the USA about knowledge appropriate to metabolic syndrome reported that, among university students, health science majors had greater knowledge than non-health science majors. In fact, it could be explained that courses in health sciences would have covered the topic of metabolic syndrome more than in other fields (Yahia, Brown, Rapley, \& Chung, 2014). Similarly, a study that compared medical and nonmedical students using samples from three universities in Northeastern China found that the level of knowledge about appropriate use of antibiotics was greater among medical students than non-medical students. It showed that medical students could get information about antibiotics more easily than other students or the general public (Huang et al., 2013). However, there are distinctions in knowledge levels within the health science. For example, a study about TB knowledge in Italy found that medical students were better informed than nursing students; the medical students in their study provided correct answers in most cases (from $62.2 \%$ to $99 \%$ ), and the medical students' level of knowledge was significantly higher than that of the nursing students (Montagna et al., 2014). Such studies show that major field of study influences participants' knowledge about health and medical treatments.

\section{Association between having heard of TB and knowledge}

"Heard of TB" refers to information obtained by knowing someone who has TB or through word-of-mouth, media, and attending seminars and educational programs. In this study, having heard of TB was significantly associated with knowledge about TB among university students in Indonesia. The results of the study show that most of the students had heard about TB. It could be explained by the fact that students at the Muhammadiyah university of Tasikmalaya had some seminars that related to the disease. This finding is consistent with a study in Bangladesh that found that most students stated that they had heard of TB from various sources, such as electronic media, print media, relatives and friends (Rana et al., 2015). However, interestingly, results from Serbia showed all non-medical university students in one study had heard about TB, with the majority describing it as a disease or specifically a pulmonary disease. Nonetheless, their knowledge about TB was uneven and inadequate, especially relating to the cause of the disease, mode of transmission and the sites affected (Smolovic et al., 2012)

Studies drawing participants from the general public have assessed the accuracy of knowledge obtained from different information sources. Specifically, the study from Malaysia mentioned above found that 
most respondents had previously encountered information about TB. However, knowledge of TB transmission was insufficient and the participants had some inaccurate knowledge about the disease. Comparing exposure to different types of traditional mass media, those who listened frequently to radio were more likely to have correct knowledge about tuberculosis transmission (Sreeramareddy et al., 2013). Another study in Nigeria, awareness of tuberculosis was highest among people who had learned about it from television, radio, and community members (Uchenna et al., 2014).

\section{CONCLUSION}

This study identifies the factors that influence students' knowledge about TB in Indonesia. Health promotion among students at Muhammadiyah University of Tasikmalaya is very important to improve their knowledge related to TB disease, especially about the cause, transmission, and symptom of the disease. The findings could be used by the university design strategic programs that measure knowledge about TB among their students. The further study could be developed to look for other factors, such as culture, information/mass media, job, and economy, that may influence knowledge of different population groups or in different areas. These results can provide evidence for the field of academic nursing to devise programs about TB prevention for university students in Indonesia.

\section{ACKNOWLEDGEMENTS}

We wish to express our appreciation to all respondents who participated in this study for valuable assistance during data collection.

\section{CONFLICTS OF INTEREST}

Neither of the authors have any conflicts of interests that would bias the findings presented here.

\section{REFERENCES}

1. Ahmad, R. A., Richardus, J. H., \& de Vlas, S. J. (2012). Care-seeking behaviour among individuals with TB symptoms in Jogjakarta Province, Indonesia: a community-based study. International health, 5(1), 51-57.

2. Amsler, C., Doser, M., Antonelli, M., Asner, D., Babu, K., Baer, H., \& Beringer, J. (2008). Cost of tuberculosis diagnosis and treatment from the patient perspective in Lusaka. Zambia. The International Journal of Tuberculosis and Lung Disease: Elsevier.

3. Asuquo, A. E., Pokam, B. T., Adindu, A., Ibeneme, E., \& Obot, V. (2014). Health-related quality of life (HRQoL) of tuberculosis (TB) patients in Akwa Ibom State, Nigeria. Journal of Tuberculosis Research, 2(04), 199.

4. Depkes, R. (2011). Pedoman Nasional Pengendalian Tuberkulosis. Cetakan Edisi ke-2. Jakarta, ISBN.

5. Dewi, C., Barclay, L., Passey, M., \& Wilson, S. (2016). Improving knowledge and behaviours related to the cause, transmission and prevention of Tuberculosis and early case detection: a descriptive study of community led Tuberculosis program in Flores, Indonesia. BMC public health, 16(1), 740 .

6. Dhuria, M., Sharma, N., \& Ingle, G. (2008). Impact of tuberculosis on the quality of life. India. Indian journal of community medicine: official publication of Indian Association of Preventive \& Social Medicine, 33(1), 58.

7. Dhuria, M., Sharma, N., Singh, N. P., Jiloha, R. C., Saha, R., \& Ingle, G. K. (2009). A study of the impact of tuberculosis on the quality of life and the effect after treatment with DOTS. India. Asia Pacific Journal of Public Health, 21(3), 312-320.

8. Diaz-Quijano, F. A., Martínez-Vega, R. A., Rodriguez-Morales, A. J., Rojas-Calero, R. A., Luna-González, M. L., \& Díaz-Quijano, R. G. (2018). Association between the level of education and knowledge, attitudes and practices regarding dengue in the Caribbean region of Colombia. BMC public health, 18(1), 143.

9. Easwaran, M., Ramachandran, D., Ramasamy, R., George, N., Mathew, M., Bazroy, J., \& Singh, Z. (2015). Knowledge, attitude, and practice regarding tuberculosis among rural population in Tamil Nadu. Tamil Nadu. Int J Med Sci Public Health, 4(12), 1681-1684.

10. Farias, Medeiros, Paz, Lobo, \& Ghelman. (2013). Completeness in caring: study of quality of life in clients with tuberculosis. Brazil. Escola Anna Nery, 17(4), 749-754. 
11. Fatiregun, Ojo, \& Bamgboye. (2009). Treatment outcomes among pulmonary tuberculosis patients at treatment centers in Ibadan, Nigeria. Annals of African Medicine, 8(2).

12. Freitas, Popolin, Touso, Yamamura, Rodrigues, Santos Neto, Arcêncio. (2015). Factors associated with knowledge about tuberculosis and attitudes of relatives of patients with the disease in Ribeirão Preto, São Paulo, Brazil. Revista Brasileira de Epidemiologia, 18(2), 326340.

13. Haasnoot, P. J., Boeting, T. E., Kuney, M. O., \& van Roosmalen, J. (2010). Knowledge, attitudes, and practice of tuberculosis among Maasai in Simanjiro District, Tanzania. The American journal of tropical medicine and hygiene, 83(4), 902-905.

14.Hoa, N. P., et.,al. (2009). Knowledge, attitudes, and practices about tuberculosis and choice of communication channels in a rural community in Vietnam. Vietnam. Health Policy, 90(1), 8-12.

15.Hossain, S., Zaman, K., Quaiyum, A., Banu, S., Husain, A., Islam, A., \& van Leth, F. (2015). Factors associated with poor knowledge among adults on tuberculosis in Bangladesh: results from a nationwide survey. Bangladesh. Journal of Health, Population and Nutrition, 34(1), 2.

16.Huang, Y., Gu, J., Zhang, M., Ren, Z., Yang, W., Chen, Y., \& Zhang, F. (2013). Knowledge, attitude and practice of antibiotics: a questionnaire study among 2500 Chinese students. China. BMC medical education, 13(1), 163.

17.Jackson, S., Sleigh, A., Wang, G., \& Liu, X. (2006). Poverty and the economic effects of TB in rural China. China. The International Journal of Tuberculosis and Lung Disease, 10(10), 11041110.

18.Kemenkes. (2014). Pedoman nasional pengendalian tuberkulosis. Direktorat Jendral Pengendalian Penyakit Dan Penyehatan Lingkungan. Indonesia, ISBN, 978-979.

19.Kemenkes. (2015). Rencana Aksi Nasional ProgrammaticManagement of Drug Resisteance Tuberculosis Pengendalian Tuberkulosis Indonesia 2011-2014. Indonesia, ISBN

20.Leung, Y., Ip Chan, J., Yoshida, E., Wu, H.-X., \& Daly, P. C. (2006). A cross-sectional analysis of acute hepatitis $B$ virus reported to the Vancouver Coastal Health Authority from 2000 to 2003. Canadian Journal of Gastroenterology and Hepatology, 20(7), 471-474.

21.Lock, W. A., Ahmad, R. A., Ruiter, R. A., van der Werf, M. J., Bos, A. E., Mahendradhata, Y., \& de Vlas, S. J. (2011). Patient delay determinants for patients with suspected tuberculosis in Yogyakarta province, Indonesia. Tropical
Medicine \& International Health, 16(12), 15011510.

22. Mohamed, A., Yousif, M., Ottoa, P., \& Bayoumi, A. (2007). Knowledge of tuberculosis: a survey among tuberculosis patients in Omdurman, Sudan. Sudanese Journal of Public Health, 2(1), 22.

23. Mondal, M., Nazrul, H. M., Chowdhury, M., \& Howard, J. (2014). Socio-demographic factors affecting knowledge level of Tuberculosis patients in Rajshahi City, Bangladesh. African health sciences, 14(4), 855-865.

24. Montagna, M. T., Napoli, C., Tafuri, S., Agodi, A., Auxilia, F., Casini, B., \& Fortunato, A. (2014). Knowledge about tuberculosis among undergraduate health care students in 15 Italian universities: a cross-sectional study. BMC public health, 14(1), 970.

25. Morris, M. D., Quezada, L., Bhat, P., Moser, K., Smith, J., Perez, H., \& Rodwell, T. C. (2013). Social, economic, and psychological impacts of MDR-TB treatment in Tijuana, Mexico: a patient's perspective. The International Journal of Tuberculosis and Lung Disease, 17(7), 954960.

26. Murray, C. J., Ortblad, K. F., Guinovart, C., Lim, S. S., Wolock, T. M., Roberts, D. A., \& Brown, J. C. (2014). Global, regional, and national incidence and mortality for HIV, tuberculosis, and malaria during 1990-2013: a systematic analysis for the Global Burden of Disease Study 2013. The Lancet, 384(9947), 1005-1070.

27. Ndwiga, J. M., Kikuvi, G., \& Omolo, J. O. (2016). Factors influencing knowledge on completion of treatment among TB patients under directly observed treatment strategy, in selected health facilities in Embu County, Kenya. The Pan African Medical Journal, 25.

28. Rana, M., Sayem, A., Karim, R., Islam, N., Islam, R., Zaman, T. K., \& Hossain, G. (2015). Assessment of knowledge regarding tuberculosis among nonmedical university students in Bangladesh: a cross-sectional study. BMC public health, 15(1), 716.

29. Rutherford, M. E., Ruslami, R., Anselmo, M., Alisjahbana, B., Yulianti, N., Sampurno, H., ... Hill, P. C. (2013). Management of children exposed to Mycobacterium tuberculosis: a public health evaluation in West Java, Indonesia. Bulletin of the World Health Organization, 91(12), 932941A.

30.Smolovic, M., Pesut, D., Bulajic, M., \& Simic, M. (2012). Knowledge and attitudes towards tuberculosis in non medical students University of Belgrade. Pneumologia, 61(2), 88-91 
31. Sreeramareddy, C. T., Kumar, H. H., \& Arokiasamy, J. T. (2013). Prevalence of selfreported tuberculosis, knowledge about tuberculosis transmission and its determinants among adults in India: results from a nationwide cross-sectional household survey. India. BMC infectious diseases, 13(1), 16.

32.Sule, A. G., Odeigah, L. O., Alabi, K. M., Issa, B. A., Shittu, R. O., Joseph, A. I., \& Natie, B. N. (2014). Quality of Life of Patients with Tuberculosis in a Nigerian Teaching Hospital. Nigeria. anxiety, 12(13), 14.

33.Triasih, R., Padmawati, R., Duke, T., Robertson, C., Sawyer, S., \& Graham, S. (2016). A mixedmethods evaluation of adherence to preventive treatment among child tuberculosis contacts in Indonesia. Indonesia. The International Journal of Tuberculosis and Lung Disease, 20(8), 10781083.

34.Uchenna, O. U., \& Ngozi, C. J. (2014). Assessment of tuberculosis-related knowledge, attitudes and practices in Enugu, South East Nigeria. Journal of Infectious Diseases and Immunity, 6(1), 1-9.

35.Vukovic, D., Nagorni-Obradovic, L., \& Bjegovic, V. (2008). Knowledge and misconceptions of tuberculosis in the general population in Serbia. Serbia. European journal of clinical microbiology \& infectious diseases, 27(9), 761-767.

36.Wang, J., Fei, Y., Shen, H., \& Xu, B. (2008). Gender difference in knowledge of tuberculosis and associated health-care seeking behaviors: a cross-sectional study in a rural area of China. China. BMC public health, 8(1), 354.

37.WHO. (2006). Diagnostic and treatment delay in tuberculosis. Geneva, WHO Press

38.WHO. (2015). Global tuberculosis report 2015. WHO/HTM/TB/2015.22: Geneva, WHO Press.

39. Widjanarko, B., Gompelman, M., Dijkers, M., \& van der Werf, M. J. (2009). Factors that influence treatment adherence of tuberculosis patients living in Java, Indonesia. Patient preference and adherence, 3, 231.

40. Yahia, N., Brown, C., Rapley, M., \& Chung, M. (2014). Assessment of college students' awareness and knowledge about conditions relevant to metabolic syndrome. USA. Diabetology \& metabolic syndrome, 6(1), 111.

41. Yin, Z., Geng, G., Lan, X., Zhang, L., Wang, S., Zang, Y., \& Peng, M. (2013). Status and determinants of health behavior knowledge among the elderly in China: a community-based cross-sectional study. BMC public health, 13(1), 710.

42. Yousif et al. (2010). Knowledge,Attitude and practice regarding Tuberculosis : CommunityBased Study in Al-anbar Governorate; Iraq. Middle East Journal of Family Medicine, 7(1), 223-230. 